\title{
Fibich's Disciple Otakar Ostrčil and His Suite in C Minor
}

\author{
Filip Válek
}

Zdeněk Fibich left behind several disciples when he died in 1900. Otakar Ostrčil (1879-1935) was one of them and he was also recognized as Fibich's successor. Let us follow Ostrčil's compositional activity after his teacher's death and focus on Ostrčil's Suite in c minor (played for the first time by the Czech Philharmonic Orchestra in Prague on 8 March 1914 and conducted by the composer). We can detect in Ostrčil's Suite the composer's maturity and a modern expressive expression that had not been applied before to such an extent in the Czech lands.

Otakar Ostrčil received piano lessons from Adolf Mikš and tried his hand at composing short pieces from childhood. When he was 16 he came to Fibich, with whom he developed his piano-playing and learnt composition. Fibich became his well-beloved master and Ostrčil Fibich's "famulus" as they named each other in their correspondence. ${ }^{1}$ As the master's confidant and almost a family member he had the opportunity to learn Fibich's compositional style. He was even allowed to orchestrate several parts of Pád Arkuna [The Fall of Arkun]. In the years 1897-1901 he was a student of modern philology and Czech studies at Charles University and he also attended Otakar Hostinskýs lectures on aesthetics. From 1903 he taught Czech and German language at the Czech-Slavonic Commercial Academy in Prague. Even after Fibich's death Ostrčil followed his master's compositional style, and eventually in 1903 he finished the opera Vlasty skon [Vlasta's Decease]. ${ }^{2}$ The libretto passed from Bedřich Smetana by Zdeněk Fibich and even Antonín Dvorák to Ostrčil himself. ${ }^{3}$ Thanks to this opera especially Ostrčil came to the notice of Prague's cultural circles as a young, promising composer and Fibich's disciple.

\footnotetext{
1 See e.g. the article: Jaroslav Vanický, “Ostrčil a Fibich” [Ostrčil and Fibich], in: Josef Plavec (ed.), Sbornik pedagogické fakulty University Karlovy [Miscellany of the Pedagogical Faculty of Charles University] (Prague, 1966), p. 169-179.

2 The storyline of the opera was drawn from Czech mythology and it continued freely from Fibich's opera Šárka.

3 See ibid. p. 169 , note 3.
} 
Ostrčil was interested in progressive music, and before he finished Vlasty skon, a Gustav Mahler cult was forming in Prague alongside others, e.g. the Richard Strauss cult. ${ }^{4}$ The Prague mahlerovství [Mahlerism], as Vladimír Lébl named the phenomenon in his study, ${ }^{5}$ took place in the Czech and German territories in the years 1898-1918. Ostrčil absorbed the work of both composers, and Mahler especially endeared himself to his heart. In 1901 Otakar Ostrčil and his friend Zdeněk Nejedlý availed of the opportunity to listen to Gustav Mahler's music for the first time. According to extant sources the music had already captivated him in 1902, when he wrote in a letter to Nejedlý: "The first one [Mahler's symphony] I have already played and now I would go through fire for Mahler." 6 Later (especially after 1910) Ostrčil and Nejedlý became active promoters of the Mahler cult. Otakar Ostrčil promoted Mahler's work as a pianist and conductor. In the years 1898-1918 65 performances of Mahler's pieces took place in Prague and Otakar Ostrčil participated in 17 of them. Put in percentage terms he realized $26 \%$ of concerts, and if we leave aside the German production, in the Czech production Ostrčil was involved in $49 \%{ }^{7}$ Zdeněk Nejedlýs acceptance of Mahler was not sudden or immediately positive. However, after developing his opinions he became unquestionably the head initiator, organizer of and speaker on Czech Mahlerism and the peak of this activity coincided with the years 1911-1913.

Ostrčil's inner relationship to Mahler also influenced his own compositional activity. We can trace the influences of Mahler's work in Ostrčil's premature attempts. In Ostrčil's Symphony in A major, Op. 7, finished in 1905, where he continues from Fibich in the melodic writing, harmony, form and use of the orchestra, Nejedly ${ }^{8}$ identifies a particular melodic similarity to Mahler's melodic "banalities" and their acoustical application in the function of parody and satire. ${ }^{9}$ In the opera Kunálovy oći, Op. 11 from the year 1908, according to Nejedly's opinion, a move to Mahler's style of expression happens in the

4 We can find in Ostrčil's opera Kunálovy oči [Kunal's Eyes] hints of the inspiration of Strauss's Salome. See e.g. Zdeněk Nejedlý, Otakar Ostrčil. Vzrůst a uzrání [Otakar Ostrčil. Growth and Maturity] (Prague, 1935), p. 141-142.

5 Vladimír Lébl, “Pražské mahlerovství let 1898-1918” [The Prague Mahlerism of the Years 1898-1918], Hudební věda [Musicology], 12 (1975), p. 99-135.

6 Stanislava Zachařová (ed.): Zdeněk Nejedlý - Otakar Ostrčil. Korespondence [Zdeněk Nejedlý - Otakar Ostrčil. Correspondence] (Prague, 1982), p. 27.

7 Vladimír Lébl, "Pražské mahlerovství let 1898-1918”, Hudební věda, 12 (1975), p. 99-135, or Filip Válek, Otakar Ostrčil: Suita c moll pro velký orchestr [Otakar Ostrčil: Suite in c minor for Large Orchestra], Op. 14, Bachelor thesis in Musicology, Palacký University, Olomouc, 2009.

8 Nejedlý monitored Ostrčil's musical development carefully, and proof is provided in a detailed monograph of Ostrčil's life. It is a fact that at first Nejedlý disapproved of elements of Mahler's style in Ostrčil's work according to reviews of Ostrčil's pieces in periodicals. Later and gradually Nejedlý began to recognize Mahler as a genius and barely admitted these elements in Ostrčil's pieces. Nejedlý prepared a multi-volume monograph of Gustav Mahler with a dedication to Ostrčil. Only the first volume has been published.

9 Zdeněk Nejedlý, "Moderní symfonie” [The Modern Symphony], Osvěta [Enlightenment], 36 (1906), p. 557. 
overture to the $3^{\text {rd }}$ act and subsequently; while it is Ostrčil's musical language it is as if he "[...] approached his drama with a Mahler symphony at heart." ${ }^{10} \mathrm{He}$ achieved a strong Mahlerian style of expression by the application of a coherent acoustic flow of symphonic music where vocal parts are built quasi-additionally above the underlying motion.

Ostrčil's musical language is modernized along with other pieces by a tectonic relieving of the above-mentioned acoustic flow and by the application of free polyphony in order to achieve expressivity in concords. We can also discover a greater attempt to add distinctiveness to the voices of separate instruments or groups of instruments. However, this happens within the frame of their natural acoustic qualities, no longer by that time unconventional techniques of playing. While we can find moderate signs of the modern expressive style as early as in the $3^{\text {rd }}$ act of Kunálovy oči, it is far more remarkable in the comical one-act opera Poupe [Flower-bud], Op. 12, from the year 1910 and in the orchestral Impromptu, Op. 13, from the year 1911. In the Suite in c minor, Op. 13, from the year 1912 in comparison with e.g. the Impromptu we can already hear a maturity and masterful acoustical application and by that time the most progressive form of his modern expression. ${ }^{11}$

The Suite in c minor is generally numbered among Ostrčil's pieces influenced by the Mahler cult. Otakar Ostrčil wrote the Suite from 25 December 1911 to 7 September 1912. He set out on the career of a promising composer, and he was also the conductor of the non-professional Orchestral Association (led by Ostrčil from 1908), which in several years was brought to such a high level of performance that it was able to compete even with the Czech Philharmonic Orchestra.

Speaking about the modernization of Ostrčil's musical language in the Suite we can find a remarkable distinctiveness of instrumentation. To a certain extent it is similar to Mahler's method of work with instruments; however, in Ostrčil's version it sounds as it were more chamber-like and modern. To another element of Mahler's style belongs e.g. the use of gradation and following sudden tapered reduction of the huge sound. The Suite is also full of dance idioms typical of Mahler. Both composers have in common the artistic employment of contrasts between "banalities" and master elaboration (Ostrčil's Suite in c minor approaches the form of a symphony with its seriousness of purpose). As well as Mahler, Ostrčil used marching themes and he included beautiful melodies in the style of Mahler's adagios. He was also inspired by the symphonic revival of generic "fossils". Despite these similarities we must claim Ostrčil's own musical language as a prevailing factor in the Suite. It is not a composition in the style of Mahler but it is an individual expression with elements of Mahler's style.

In the Suite Ostrčil tried to handle anew and form a certain musical material, identify and exhaust the capacity of musical ideas by developing them and especially by

10 Zdeněk Nejedlý, Otakar Ostrčil. Vzrůst a uzrání (Prague, 1935), p. 141-142.

11 Among the orchestral compositions we consider Kř́žová cesta [The Stations of the Cross], Op. 24, from the year 1928, as a pinnacle of his "flow of modernization". In the case of this piece, however, we are only able to speculate if Ostrčil's starting point was inspired by Mahler and further elaborated or if it is an approach to the style of the $2^{\text {nd }}$ Viennese School. 
a reciprocal confrontation between them. Neither the novelty of the musical invention nor the novelty of its methods is a strongpoint of the Suite, it is rather their unconventional, non-romantic use. ${ }^{12}$ The Suite technically incorporates five movements of different characters (Pochod [March], Scherzino, Variace [Variation], Serenáda [Serenade] and Fuga [Fugue]) which are precisely masterful types of a new, linear way of formation..$^{13}$ Using a combination of the then-prevailing attitude and the contemporary view it is possible to recognize clearly in the Suite tendencies and trends (often even contradictions) that appeared in the music of the early $20^{\text {th }}$ century. The most noticeable of these are Romanticism, expressionism and a certain anticipation of neoclassicism.

Generally the musical material employed gives evidence of Romanticism: Ostrčil worked with everything that the $19^{\text {th }}$ century could offer. ${ }^{14}$ The resource of Ostrčil's musical language lies in his teacher Zdenĕk Fibich; he upgraded it later with a study of late romantic composers' works. In the Czech text Ostrčil belonged to the purest representatives of Central-European Romanticism as well as Mahler (he did not apply the tendency to tap into the modal wealth of a national tradition, nor did he arrange folk songs). This is what Lébl mentioned when he contrasted Ostrčil with the "East European" orientation of Vítězslav Novák (whose aesthetics by that time dominated Czech modernism) and Leoš Janáček. ${ }^{15}$ Ostrčil followed the orientation of the Czech musical "lumírovství" after Fibich and Foerster, and he never left the Romantic ideals of greatness and nobility (he preferred a moral and ideological mission). He became immune from impressionistic trends; from his point of view he must have considered them too petty and superficially playful. Therefore he saw the gradation of tension as the only possible starting point of further musical development and of overcoming the late-romantic crisis. Thus for the first time in the Czech lands he introduced expressionism although he never became an unconditional supporter. ${ }^{16}$ On the other hand Ostrčil's aim was not the expression of continual tension (so typical for pure expressionism), merely the possibility to use this element.

When listening to the Suite the above-mentioned expressivity is immediately remarkable. Many of Ostrčil's contemporary composers commenting on his music saw the source of this expression in the rigorous method of linear voice-leading of individual parts in the orchestra (several authors even claimed that it was a strict polyphonic leading of parts or that this expression developed from a polyphonic way of thinking). Only Jaroslav Jiránek ${ }^{17}$

12 Ostrčil saw his resource in terms of an understood sense of Romantic ideals. He "inwardly" eliminated his Romanticism by a dissolution of the relics of classical aesthetics (i.e. the rules of chorddistribution), and he set out on the journey of a gradation of tension.

13 See the composer's Dějiny české hudební kultury. Díl I. 1890-1918 [The History of Czech Musical Culture, vol. 1, 1890-1918], (Prague, 1972), p. 158.

14 By the way, Mahler did the same thing, only with the difference that it was so striking that it could shock the listeners, which was one of his intentions.

15 Zdeněk Nejedlý, Otakar Ostrčil. Vzrůst a uzrání (Prague, 1935), p. 128.

16 Jaroslav Jiránek, “Ostrčilův stylový př́inos a jeho vnitřní polarita” [Ostrčil’s Stylistic Contribution and His Inner Polarity], Hudební věda, 5 (1968), p. 549-553.

17 Ibid. 
exploded the myth: although Ostrčil was applying a linear approach to the individual parts, he was more attentive to concords than keeping the linearity rigorously. For Ostrčil the specific creation of contrasted, acoustically coloured areas ("Klangfarbenmelodie") is achieved by a thickening and thinning of concords in the area of composition. This linearity is applied as an expressionistic element in particular sections of the Suite, used for expressive and structurally logical purposes. It is applied as an orchestrally spatial method of construction which means that it achieves a thickening of the vertical axis by an orchestral workmanship against the high-romantic way of harmonic accumulation. In the craftsmanship of the composition we can find powerful gestures and contrasts caused by the confrontation of musical material by separate instruments or groups of instruments (the confronted motives are, however, tonal, eventually employing an extended tonality). From the contemporary point of view (when we have experienced e.g. the $2^{\text {nd }}$ Viennese School and dodecaphony) we can perceive Ostrčil's expressivity as it is very polished; however, in the Czech territory at the time, with the dominating impression of modernism in the works of V. Novák and J. Suk, this kind of act was very meaningful.

Ostrčil's constructivistic elements and rational working of material in the years before World War I indicated an orientation toward the development of expressionist modernism, though from a recent reading of the Suite many elements could refer to the anticipation of neoclassicism (as Očadlík pointed out ${ }^{18}$ ). First of all it could be its tendency towards the form of a suite (instead of the choice of a symphony, for instance) and its non-romantic elaboration (let us recall Helfert's placing of Ostrčil's gradual shift to tectonic objectivism against the subjectivism of the aesthetics of V. Novák and J. Suk ${ }^{19}$ ). While Ostrčil chose purely musical names for the parts of the Suite, it is the conventional content of the suite, i.e. units of the dance or less heavy character (individual parts are in transparent ternary ABA' form; in conclusion there is a monumental fugue) that Ostrčil upgrades and "enlivens" with the elaboration. Other strong elements pointing to neoclassicistic tendencies are: the clarity but at the same time brilliance of Ostrčil's instrumentation, the use of natural ranges and timbres of musical instruments, the use of distinctive, easy-to-remember melodic writing, the connection of extramusical content with authentic music principles, uniform works combining compositional, melodic and dynamic climaxes and a fixed form.

Ostrčil's transition from Romanticism to a modern expression was distinguished by a remarkable developmental continuity and, at the same time, intensive dynamic progress. This was caused by a consistent unexpressed sense of Romantic ideals, which Ostrčil retained all his life. Only now can we speculate which journey would Fibich have set out for, if he had lived to a greater age. Would the journey have been similar to Ostrčil's one or completely different? Who knows, but it is clear which way was chosen by his disciple Otakar Ostrčil.

18 Mirko Očadlík, Svět orchestru. České orchestrální skladby. 2. díl [The World of the Orchestra, Czech Orchestral Compositions, Vol. 2] (Prague, 1946), p. 408-413.

19 Vladimír Helfert, Česká moderní hudba [Czech Modern Music] (Olomouc, 1936), p. 74-81. 


\section{Der Fibich-Schüler Otakar Ostrčil und seine Suite c-Moll}

\section{Zusammenfassung}

Otakar Ostrčil (1879-1935), einer der letzten Schüler von Zdeněk Fibich und als Komponist sein Nachfolger, komponierte zuerst im Stil seines Lehrers und ist erst allmählich zu seiner eigenen kompositorischen Handschrift gekommen. Im Prager Musikleben war er bereits mit seiner Oper Vlasty skon (Vlastas Tod, 1903) bekannt geworden, doch eine modernere, originale Musiksprache kann erst in seiner Suite c-Moll (1912) gefunden werden. Das Werk wurde in jenen Jahren komponiert, in denen in Prag ein Gustav MahlerKult (1898-1918) herrschte. Ostrčil hat Mahlers Musik geliebt und war als Pianist und Dirigent einer ihrer aktivsten Propagatoren. In der Suite c-Moll von Otakar Ostrčil findet man also romantische musikalische Mittel, an Mahler erinnernde Elemente, aber auch die des Expressionismus sowie Anzeichen der Neoklassik. Die Originalität des Werkes bleibt jedoch unbestritten; es spricht mit Ostrčils eigener Musiksprache.

\section{Fibichův žák Otakar Ostrčil a jeho Suita c moll}

\section{Shrnutí}

Otakar Ostrčil (1879-1935) byl jedním z posledních žáků a skladatelských pokračovatelů Zdeňka Fibicha. Nejprve komponoval v mistrově stylu, ale postupně začal uzrávat jeho osobitý skladatelský rukopis. Do širšího pražského kulturního povědomí se jako skladatel zapsal už operou Vlasty skon (1903), ale modernější vyjadřovací jazyk ve zralé formě najdeme v jeho Suitě c moll (1912). Tato skladba vznikla v době velkého kultu Gustava Mahlera v Praze, který trval v letech 1898-1918. Ostrčil Mahlerovu hudbu miloval a stal se jedním z hlavních aktivních propagátorů Mahlerova kultu v roli klavírního hráče a dirigenta. Ve Suitě c moll Otakara Ostrčila lze především nalézt hudební materiál romantismu, stopy Mahlerových prvků, dále i prvky expresionismu a přibližení se neoklasicistnímu stylu. Vše ale zkomponoval v originálním stylu, proto je ve skladbě nutno konstatovat především vlastní Ostrčilovu hudební řeč jako převažující činitel.

\section{Keywords}

Otakar Ostrčil; Suite c minor (1912); Mahler's Reception in the Czech lands. 